\title{
Dukuhseti Pati in Literature and Social Reality: A Perception About Women
}

\author{
Laura Andri Retno $M^{*}$ and Khotibul Umam \\ Departement of Indonesian Literature, Faculty of Humanities, Diponegoro University
}

\begin{abstract}
Prostitution is a phenomenon in people's lives and is considered a "social problem". The condition of women as objects also appears in literary works, as a reflection of the perception of their society. Therefore, studies are needed in the perspective of feminism, especially radical feminists to explore the issue of prostitution that occurs in women. Feminist Literary Critical Approach is carried out in this study with the type of qualitative research. Data were collected from female sex worker informants and formal figures with in-depth interview techniques and field data observations.
\end{abstract}

Keywords: Perception, Women, Prostitution, Feminism.

\section{Introduction}

Dukuhseti Village is a village located north of the Java Sea, precisely in the Dukuhseti District area, Pati Regency, Central Java, which borders Kembang Village, Banyutowo Village, Alasdowo Village, Grogolan Village and Negara forest. Has a population of 8,982 people and 2645 households. Livelihoods in the community of Dukuhseti farmers 2370 people, 1232 farm workers, 95 fishermen, 21 business people, 774 industrial workers, 870 construction workers, 36 traders, 36 transportation workers, 15 Civil Servants, retired 217 people 5656 people.

Prostitution is a long-standing "community disease". The definition of "community disease" is all behavior that is contrary to the norms of goodness, local stability, patterns of simplicity, morals, property rights, family solidarity, living in harmony, discipline, and formal law. Prostitution is also referred to as a "social problem" which is all forms of behavior that violates or rapes the customs of the community and harms the people (Anwar in Wakhrudin, 2008).

The views of the outside community towards the condition of prostitution in Dukuhseti Village have an impact on the description of women in fictional texts, such as novels. The novel contains a collection of short stories titled Genduk Dukuhseti by Rohana Handaningrum, published in 2014, is a representation of literary works from real world reality. The birth process of these literary works is initiated by the socio-cultural code that

\footnotetext{
${ }^{*}$ Corresponding author : lauraandrirm01@,gmail.com
} 
surrounds the author. As a cultural text, the literary work represents the community and all the systems that surround it be it political, economic, power, social, and so on.

So that the female characters in the novel whose existence is always not neutral from the author's ideology can be dug out properly and thoroughly then an analysis that is not gender biased is needed. In other words, the analysis of women's problems must be done through the perspective of women. This is what Hellwig called "reading as a woman" (Hellwig, 2003: 10) in analyzing the problems of women expressed in texts or novels [1]. By doing so, it is hoped that through this research a correlation can be found between Dukuhseti women in social reality represented through literary works.

\section{Research Methods}

Radical feminism is one of the theories in feminist literary criticism that can be used to examine women's body problems. The female body is the main object of oppression by male power. Therefore, radical feminism issues including body and reproductive rights, sexuality (including lesbianism), sexism, power relations between women and men, and private-public dichotomy.

Based on the theory used above, the method used in this study is a qualitative descriptive method. Qualitative research is research that intends to understand phenomena about what is experienced by research subjects such as behavior, perception, motivation, actions, etc. holistically, and by means of descriptions in the form of words and language (Moleong, 2007: 6). In addition to being qualitative, this research is a library research study, with the main source of the novel Genduk Dukuh Seti by Rohana Handaningrum (2014). Related to this, information sources, such as books, papers, articles and research results that have relevance to the topic of this study are used to sharpen the results of the study [2].

\section{Discussion}

Prostitution is often referred to as prostitution (from Latin pro-stituere or prostauree) means to allow oneself to commit adultery, commit prostitution, fornication and concubinage [3]. Bonger (1950) said that prostitution is a social phenomenon with women who sell themselves doing sexual acts as a livelihood. The activity of peddling sex or prostitution is considered bad by the community because it is contrary to the values of goodness, morals, and religion. Even so, the phenomenon of prostitution has existed for a long time as said by Dr. J. Verkuyl (in Hull, Sulistyaningsih and Jones; 1997) [4]. Regardless of people's views on the life of prostitution, the reality still proves that prostitution in the social system of society, its presence since centuries ago and no one force can erase it from this earth (Atmaja, 2012) [5].

Dukuhseti Village is an area where the majority of the population works as farm laborers, brick-making workers, fishers and factory workers. The lack of community income has resulted in the emergence of pockets of poverty in Dukuhseti Village. Women with low skills and education work as prostitutes to get high salaries.

\subsection{History of Prostitution in Dukuhseti}

The practice of prostitution in Dukuhseti arose because of several events that occurred, namely the presence of migrant workers from China coming to Dukuhseti through the nearby Juwana Port. Not only from abroad, migrant workers who come from other regions are also there. They work in sugar factories, rubber plantations and teak. Many workers are associated with local women, some are even married. 
Another cause of the growth of prostitution in Dukuhseti was marked by the political party campaign that began in 1972. If there were officials who came either from the district or higher then the women in Dukuhseti were asked to become their posse, then by order of the village head, they were also made to satisfy officials' desires officials earlier (Results of interviews with Mr. Sapardi, Kembang).

Another element influencing prostitution in Dukuhseti Village is culture. Folklore as part of the culture developed and was recognized by the community for its truth. Brojoseti's story is an oral literature used to legitimize prostitution there. According to the story, Brojoseti is the founder figure of the village of Dukuhseti who has a very beautiful wife. Unfortunately, the wife had an affair and was caught red-handed by Brojoseti. Brojoseti was furious and then cursed his wife and all the village women that from that moment on they would always be inclined [4]. People still believe in this story. But it could be that the story was deliberately brought up as a justification for institutionalizing the culture of infidelity or even prostitution. Society becomes very loose, as far as sex is concerned. For them, prostitution is already a letter of destiny [5].

\subsection{Conditions of Prostitution in Dukuhseti Now}

Prostitution activities in Dukuhseti are not as busy as the 1970s to 1984. But it cannot be said that these activities have been completed. From the data obtained from interviews with Mr. Supardi (District Social Welfare Workers) in 2018 the number of sex workers in Dukuhseti Village has decreased. In 1984 there were 150 people and in 2018 there were 35 people. In 1984 there were 150 people and in 2018 there were 35 people. They no longer carry out prostitution in Dukuhseti. These pimps reap the benefits of the entire prostitution system that is obtained from prostitution by way of payment. In addition, there are sex workers who only serve in areas outside the village, for example in salons, coffee shops, small hotels around Dukuhseti or karaoke in Pati.

The number of sex workers is reduced due to five things, namely: a) Awareness of religion, which was quite effective in reducing the number of prostitution in Dukuhseti. b) Narrowing the place of localization, the community realized the negative stigma of prostitution which made them narrower, and they began to change the localization into residences, shops, places of worship or community shops. c) HIV, AIDS disease and others. d) The transition from sex workers to women workers, working abroad with almost the same income when they become sex workers is considered quite prestigious and promising to save the economic conditions of the family. e) Assistance and counseling provided by the Office of Social Affairs in providing mentoring and counseling. The Office of Social Affairs also provides assistance for socially vulnerable women.

\subsection{Factors That Cause Prostitution Still Persists in Dukuhseti}

The results of interviews conducted with several respondents, there are similarities in the data submitted about the motivation of respondents to do work as a prostitute, namely economic factors. But in subsequent interviews and related to the sociological conditions of the Dukuhseti community. The percentage that can be made is $50 \%$ economic factors and $20 \%$ biological factors (satisfaction), 20\% environmental factors and 10\% psychological factors (bad marriage life, sexual harassment, family trauma).

Referring to social data, the people, especially men in Dukuhseti village, marry women who have the potential to become sex workers. These men then work for women who want to become sex workers and then send them to other areas such as Jakarta. Generally, women who worked as trailers previously had married first or at the time of marriage were still in their teens. 
In addition, the reference factor is also part of the increasing number of prostitution activities in Dukuhseti. The assumption of women in the region is that material becomes a measure of success, making prostitution more fertile. By seeing other successful prostitutes, Dukuhseti women follow and are interested in working as traffickers. This reference is a form of an imitation process that occurs in society, in which people try to imitate situations that are considered attractive, trustworthy, and convincing. When a prostitute or prostitute is seen as the quickest and easiest way to achieve prosperity, reference is also made here.

\subsection{Dukuhseti Women in Literary Works}

The Genduk Dukuhseti novel is a portrayal of Dukuhseti women who have the stability to become a teasing and enter the world of prostitution. The stability of being a prostitute is an attempt to interpret the existence of a woman as well as to show that being a prostitute means dominating and subjugating men, not being controlled and subdued by men as in a marriage institution. Through radical feminist analysis, it can be seen the form of resistance of the main character from the feeling of oppression that he experienced.

One genre of feminist thought is radical feminists. The basic assumption is that they think that oppression of women by men is rooted in the sex of the man himself and his patriarchal ideology. Thus men both biologically and politically are part of the problem. This flow assumes that physical mastery of women by men, such as sexual relations is a basic form of oppression against women [6].

Radical feminism concerns the body and reproductive rights, sexuality (including lesbianism), sexism, power relations between women and men, and private-public dichotomy. The personal is political becomes an idea that is able to reach the problems of women to the private sphere, a problem that is considered the most taboo to be raised to the public. Information or bad views (black propaganda) are mostly directed at radical feminists. The radical feminist resistance against patriarchal culture in the novel is seen in:

\subsubsection{Desire to give up virginity}

Simbok figure releases her virginity without marriage. She chose to release her virginity with men without a bond. According to her, by releasing virginity, women get the same place as men over the power over their genitals. In the novel, the symbol of explaining about sexuality between men and women through her thoughts. She chose not to care about sin because sexual relations carried out by men and women were always in the subconscious. Power relations are present when human sexual relations are in an unconscious state. This relationship makes humans see the others as objects. Humans are not related to partners as subjects to subjects, so they are never equal.

Simbok figure with her attitude against patriarchy and emphasized that women also have the right to regulate their own sex without having to be influenced by the existing social environment. Shee regained control of women's sexuality by demanding the right to practice anything that could provide pleasure and satisfaction. The ideal sexual relationship is an equal partner who both gives consent, and who negotiates to maximize sexual pleasure and satisfaction with each other, in whatever way they choose [7].

\subsubsection{Women, Sex, Body and Prostitution}

Radical feminism considers oppression of women by men, rooted in the sex of the man himself and his patriarchal ideology. This flow assumes that physical mastery of women by men, such as sexual relations is a basic form of oppression. 
In this novel Genduk Dukuhseti the author represents the society or social patterns that occur at that time where women freely do what they want with their bodies. With the slogan "the private is political", which means oppression in the private sphere is oppression in the public sphere. A statement which wants to make women aware that "women are the owners of their own bodies". Sexual and prostitution are the methods used by women to represent their bodies.

\section{Conclusion}

This research tries to reveal the relationship between social reality and literary works. How the author as part of the community represents women in literary works. Prostitution that is still rife in Desa Dukuhseti Pati and contained in the novel Genduk Dukuhseti when examined using radical feminist theory is an activity used by women to realize that "women are the owners of their own bodies". Sexual and prostitution are the means by which they represent their bodies.

\section{Reference}

1. T. Hellwig, In the Shadow of Change: Woman in Indonesian Literature, California: Univeristy of California at Barkeley (1994)

2. R. Handaningrum, Genduk Dukuh Seti. Lamongan: Pagan Press (2014)

3. K. Kartono, Patologi Sosial Jilid 1, Jakarta : Rajawali Pers (2007)

4. H. Terence Hull, Pelacuran di Indonesia: Sejarah dan perkembangannya, Pustaka Sinar Harapan bekerja sama dengan the Ford Foundation (1997)

5. D. Atmaja, 2012, Motivasi Dalam Berprotitusi Di Desa Dukuhsekti Kabupaten Pati Jawa Tengah, Artikel dalam Web Psikologi dan Pendidikan edisi tanggal 10/01/2012.

6. M. Fakih, Analisis Gender dan Transformasi Sosial Yogyakarta: Pustaka Pelajar (2001)

7. P. Rosemarie Tong, Feminist Thought, (diterjemahkan oleh Aquarini Priyatna Prabasworo, Yogyakarta: Jalasutra (1998)

8. Chamamah-Soeratno, Siti, "Penelitian Sastra: Tinjauan Tentang Teori dan Metode Sebuah Pengantar" dalam Metode Penelitian Sastra (Ed. Jabrohim), Yogyakarta: Hanindita (2003)

9. Haryanti, "Relasi Gender dalam Gadis Tangsi," Yogyakarta: Universitas Gadjah Mada (Skripsi S1, tidak untuk dipublikasikan) (2008).

10. M. Humm, Ensiklopedia Feminisme, Edisi Bahasa Indonesia diterjemahkan oleh Mundi Rahayu, Yokyakarta: Fajar Pustaka Baru (2007)

11. L. Andri Martini, "Dominasi Kuasa Perempuan Terhadap Budaya Patriarki dalam Novel Gadis Tangsi Karya Suparto BrataSebuah Tinjauan Kritik Sastra Feminis, ” Yogyakarta: Universitas Gadjah Mada (Tesis S2 tidak untuk dipublikasikan) (2014)

12. S. Reinharz, Metode-Metode Feminis dalam Penelitian Sosial, Penerbit: Women Research Institute, Indonesia (2005)

13. Ruthven, K.K, Feminist Literary Studies: An Introduction, Cambridge: Cambridge University Press (1990)

14. E. Showalter, "Towards a Feminist Poetics" in Contemporary Literary Criticism, Davis, Robert Con (ed.), London: Longman Inc (1989)

15. N. Wolf, Fire with Fire. The New Female Power and How To Use It, New York: Vintage Books (1994) 